\title{
Reoquatia
}

Malaysian Journal of Society and Space

\section{Kawasan Rukun Tetangga: Pemangkin perpaduan peringkat akar umbi masyarakat Malaysia}

\author{
Beh Sang How ${ }^{1,2}$, Pue Giok Hun ${ }^{1}$ \\ ${ }^{1}$ Institut Kajian Etnik, Universiti Kebangsaan Malaysia \\ ${ }^{2}$ Jabatan Perpaduan Negara dan Integrasi Nasional \\ Correspondence: Beh Sang How (email: p91328@siswa.ukm.edu.my)
}

Received: 22 November 2020; Accepted: 24 May 2021; Published: 27 August 2021

\begin{abstract}
Abstrak
Isu menguruskan perbedaan sosial mengikut garis etnik masih kekal menjadi satu isu yang sensitif dan kritikal dalam masyarakat multietnik di Malaysia hari ini walaupun setelah tercapainya kemerdekaan lebih daripada enam dekad yang lalu. Signifikasi faktor etnik dalam kehidupan seharian menyebabkan kerajaan giat melakukan usaha-usaha proaktif untuk memupuk perpaduan yang dikatakan masih belum tercapai. Melalui penubuhan dan pelaksanaan program Rukun Tetangga, para sarjana umumnya bersetuju bahawa program tersebut memberi kesan positif ke atas pemupukan perpaduan di peringkat akar-umbi masyarakat. Namun, adakah konsensus ini turut relevan di peringkat kebangsaan? Artikel ini bertujuan untuk mengupas pengukuran tahap kesepaduan sosial penduduk Kawasan Rukun Tetangga (KRT) dari setiap negeri dan Wilayah Persekutuan dengan menggunakan analisis deskriptif dan statistik inferensi ke atas data kuantitatif yang dikumpul menggunakan borang soal-selidik. Responden kajian adalah seramai 585 orang penduduk yang menetap di 60 buah KRT dari seluruh negara. Pendekatan purposive sampling digunakan untuk memastikan komposisi etnik responden kajian ini adalah selaras dengan komposisi etnik populasi Malaysia. Hasil dapatan kajian menunjukkan tahap kesepaduan sosial yang dicapai adalah tinggi di mana penduduk daripada pelbagai latar belakang etnik dan agama telahpun berkongsi nilai hidup dan pandangan hidup yang sama. Pengukuran kesepaduan sosial daripada enam dimensi iaitu kekitaan, keterangkuman, penyertaan, pengiktirafan, legitimasi dan kesamarataan mendapati walaupun mereka mempunyai bentuk perhubungan yang merentasi batas etnik, signifikasi faktor etnik belum terhapus sepenuhnya dalam masyarakat Malaysia. Oleh itu, walaupun kesepaduan sosial dalam masyarakat adalah kuat biarpun dalam keadaan politik dan sosioekonomi masa kini yang tidak stabil, usaha proaktif untuk memperkukuhkan perpaduan masih diperlukan.
\end{abstract}

Kata kunci: akar umbi masyarakat, hubungan antara etnik, kesepaduan sosial, Malaysia, perpaduan, Rukun Tetangga 


\title{
Kawasan Rukun Tetangga: Catalyst of unity at the grassroots of Malaysian society
}

\begin{abstract}
The issue of organizing social differences according to ethnic lines remains as a sensitive and critical issue in Malaysia's multiethnic society today despite having achieved independence more than six decades ago. The significance of ethnicity in everyday life has led to the government actively taking proactive actions in nurturing unity that remains to be achieved. From the formation and implementation of Rukun Tetangga program, scholars generally agree that it has contributed positively towards nurturing unity in the society at the grassroots regionally. However, is this applicable for Malaysian society nationwide? This article seeks to measure the level of social cohesion among the residents in Rukun Tetangga areas from every state and Federal Territory in Malaysia via descriptive and statistical inference analyses on quantitative data collected in the form of questionnaires. The total number of respondents in this study was 585 respondents who reside in 60 Rukun Tetangga areas from all over the country. The selection was done via purposive sampling to ensure the ethnic composition of the respondents in this study matches the ethnic composition of Malaysian population. The study's findings showed that the level of social cohesion achieved is high whereby residents from all walks of life already share mutual life values and outlooks. The social cohesion measured from six dimensions namely esprit de corps, inclusion, participation, recognition, legitimation, and equality, shows that although Malaysians have forged interethnic relations that transcend ethnicity, the significance of ethnicity in the society is yet to be eradicated completely. So, despite the social cohesion in the society remains strong during the political and socioeconomic instability currently, proactive measures to strengthen the unity remains much needed.
\end{abstract}

Keywords: grassroots of society, interethnic relation, social cohesion, Malaysia, unity, Rukun Tetangga

\section{Pengenalan}

Pemupukan perpaduan dalam masyarakat multietnik seperti di Malaysia sangat memerlukan usaha yang teratur, menyeluruh dan berterusan untuk memastikan penglibatan segenap lapisan masyarakat (Abd Aziz et al., 2017; Shamsul, 2011). Tragedi 13 Mei 1969 yang mengorbankan ratusan nyawa dan kemusnahan harta-benda menjadi iktibar peri-pentingnya perpaduan dicapai dalam keadaan aman dan harmoni (Majlis Gerakan Negara, 1969). Bertitik-tolak dari situ, kerajaan menerusi Majlis Gerakan Negara (MAGERAN) telah berusaha merapatkan jurang dan membina semula hubungan etnik dengan menekankan unsur perpaduan dan integrasi dalam kehidupan masyarakat (Mohd Rizal \& Shamrahayu, 2014). Satu daripada usaha-usaha tersebut adalah program Skim Rukun Tetangga yang diperkenalkan pada tahun 1975 (Kementerian Perpaduan Negara, 2021). Walaupun ianya merupakan inisiatif kerajaan, pelaksanaan program tersebut adalah berkonsepkan pertubuhan sukarela peringkat akar umbi yang bersandarkan kepada prinsip kejiranan dan kesukarelawanan dengan dipantau oleh agensi kerajaan yang khusus (Kementerian Perpaduan Negara, 2021). Kini, program Rukun Tetangga (RT) kian berkembang daripada segi 
bilangan dan peranannya mengikut keperluan semasa. Keadaan ini dilihat sebagai petanda kejayaan program RT bukan sahaja dalam aspek keselamatan (Faris et al., 2017; Norwahidah \& Novel, 2016), tetapi juga perpaduan di peringkat akar umbi masyarakat (Mohd Syariefudin et al., 2013; Budi et al., 2020). Konsensus ini tercapai tanpa mengira faktor lokaliti masyarakat tempatan yang dikaji seperti di Malaysia Timur (Budi et al., 2020) atau di Semenanjung Malaysia sama ada di kawasan yang tahap urbanisasi dan industrialisasinya tinggi seperti di Lembah Kelang (Mohd Taib et al., 2008; Hamidah, 2014; Mohd Syariefudin et al., 2017) atau di negeri-negeri lain (Faris et al., 2017; Ahmad \& Nur Syafiqah, 2014). Program RT turut diterima baik oleh masyarakat setempat di kalangan ahli-ahlinya tanpa mengira jantina (Ahmad \& Nur Syafiqah, 2014) atau umur (Wan Zumaiza et al., 2016).

Walaupun sorotan karya rata-ratanya menunjukkan konsensus yang positif seperti di atas, wacana perpaduan melalui program RT cenderung dibincang dalam konteks kewilayahan di peringkat lokaliti tertentu sahaja, misalnya di satu kawasan kejiranan, daerah atau negeri. Justeru itu, satu kajian telah dijalankan untuk mengkaji sejauh mana program RT berjaya memupuk perpaduan dengan mengukur tahap kesepaduan sosial masyarakat di Kawasan Rukun Tetangga (KRT) di seluruh negara.

\section{Konsep kejiranan dalam pemupukan perpaduan di peringkat masyarakat akar umbi melalui Rukun Tetangga}

Kefahaman yang mendalam tentang ilmu dan pendekatan sejarah adalah penting dalam memahami dan menganalisis asas pembentukan Malaysia sebagai sebuah negara bangsa. Kefahaman ini boleh dibentuk melalui dua perspektif realiti sosial yang berbeza, iaitu melalui perspektif tafsiran autoriti dan tafsiran harian (Shamsul, 2012). Perspektif tafsiran autoriti menjelaskan peristiwa atau perkara yang berlaku daripada perspektif golongan atasan atau berautoriti. Melalui perspektif ini, perpecahan dalam masyarakat multietnik Malaysia digambarkan berlaku dengan ketara dalam era kolonialisme barat khususnya British, dan pendudukan Jepun akibat pelaksanaan dasar yang rasis. Kesannya, wujud ketidakseimbangan dalam pembangunan sosioekonomi masyarakat (Del Tufo, 1949; Mohamed \& Ayu, 2017), dan syak wasangka terutamanya antara dua kumpulan etnik terbesar iaitu Melayu dan Cina (Ratnam, 1965). Kemunculan gerakan Parti Komunis Malaya dan percubaannya untuk menguasai Tanah Melayu melalui kekerasan telah memburukkan lagi keadaan hubungan antara etnik dalam masyarakat pramerdeka (Cheah, 1983; Ho, 2005). Selepas merdeka, faktor etnik terus mempengaruhi proses pembentukan negara bangsa Malaya, dan seterusnya Malaysia (Ting \& Siew, 2018; Sity \& Norrizan, 2019). Shamsul (2012) menggambarkan masyarakat pasca kolonial di Malaysia sebagai dalam 'ketegangan yang stabil' di mana ia masih berisiko untuk berpecah-belah akibat titik-titik kontradiksi yang ada dalam masyarakat (Shamsul, 2014). Ketegangan tersebut antara lain berpunca daripada kefahaman yang cetek mengenai etnik lain (Chin et al., 2015; Pue \& Kaur, 2014; Lino et al., 2017), dan layanan yang tidak sekata dalam percaturan politik dan ekonomi pihak berautoriti pada masa itu (Lau, 2014; Yang \& Md. Sidin, 2015). Ironinya, dalam usaha memerangi konflik antara etnik yang memuncak melalui Tragedi 13 Mei 1969, pihak berautoriti menggunakan pendekatan penstrukturan semula masyarakat yang mengekalkan perbedaan mengikut garis etnik. Tindakan afirmatif berdasarkan faktor etnik kekal mempengaruhi peluang hidup dan gaya hidup ahli sesebuah kumpulan etnik mengikut tafsiran autoriti hari ini, misalnya dalam isu kemiskinan (Khoo et al., 2018; Ravallion, 2019), pekerjaan (Lee \& Muhammad, 2013), dan pendidikan (Lino et al., 
2017; Joseph, 2018). Tindakan afirmatif sebegini walaupun berjaya daripada segi agihan kekayaan (Muhammad Najit et al., 2018) dan pengukuhan kedudukan istimewa etnik dan budaya Melayu dalam acuan negara-bangsa (Nazri, 2020; Mansor, 2012), ia telah mengukuhkan kedudukan etnik sebagai 'master status' warga Malaysia dan mampu mengeruhkan hubungan antara etnik jika tidak diuruskan dengan baik di peringkat autoriti (lihat Muhammad Arif et al., 2017; Anis et al., 2018; Khairul \& Rozaimah, 2020).

Namun apabila wacana hubungan etnik dibincangkan melalui perspektif tafsiran harian yang bersifat lebih mikro, tidak formal dan berdasarkan perspektif peribadi ahli masyarakat mengikut pengalaman dan aktiviti seharian (Shamsul, 2012), kerenggangan yang dikatakan wujud antara etnik adalah tidak sejelas atau senyata perspektif tafsiran autoriti. Jika berdasarkan teori batas etnik oleh Barth (1969), kekaburan jurang dalam hubungan antara etnik ini adalah disebabkan oleh sifat batas etnik yang poros telah membenarkan pergerakan individu-individu daripada satu kumpulan etnik kepada kumpulan etnik yang lain, berlaku secara berterusan. Salah satu penanda yang menyerlahkan dimensi hubungan etnik yang abstrak dan tersirat ini ialah prinsip kejiranan. Prinsip kejiranan adalah sejenis modal sosial yang terbentuk melalui perkongsian kepercayaan, nilai dan norma dalam jaringan kontak sosial sesebuah organisasi sosial yang seterusnya dapat menambahbaik keefisyenan masyarakat (Forrest \& Kearns, 2001; Scott, 2014; Putnam, 2000).

Masyarakat tradisional pada zaman prakolonial dan zaman kolonial jelas menunjukkan wujudnya prinsip kejiranan dalam kehidupan seharian melalui amalan-amalan yang lazim dikaitkan dengan budaya kampung seperti bergotong-royong dan bantu-membantu (Chia, 2013). Hal ini cenderung berlaku dalam kumpulan etnik sendiri rentetan perkongsian nilai budaya dan penglibatan dalam aktiviti adat yang sama. Namun, sorotan kajian menunjukkan prinsip kejiranan antara etnik turut wujud dalam sesebuah penempatan, sama ada dalam skala besar seperti bersawah, melangsungkan majlis keraian atau meronda mahupun skala kecil seperti menjaga anak atau rumah yang ditinggalkan untuk sementara, bertanya khabar, melawat dan menghulurkan bantuan kepada jiran yang dalam kesusahan (Raybeck, 1980; Mohd Razali, 1992, Chia, 2013).

Idea hubungan timbal-balik antara ahli komuniti di sebalik konsep kejiranan ini diaplikasi dalam pengurusan Jabatan Perpaduan Negara dan Integrasi Nasional (JPNIN). Pada tahun 1987, JPNIN mendefinisikan 'jiran' sebagai mereka yang tinggal di satu-satu kawasan perumahan atau kampung yang berhampiran. Sebagai contoh, semua penduduk di Kampung Kerinci membentuk satu kejiranan, dan Kampung Kerinci itu sendiri dikatakan sebagai satu kawasan kejiranan. Pada tahun 1989, JPNIN telah mengemukakan konsep jiran yang lebih fleksibel, yakni keanggotaan dalam keluarga yang sama, atau tinggal berhampiran dengan kediaman kita atau dalam kawasan kejiranan yang sama tanpa mengira jenis penempatan dan lokaliti.

Selain aspek keanggotaan, konsep kejiranan juga dilihat dalam aspek pengoperasian yang terjelma daripada hubungan timbal-balik jangka panjang dalam kontak sosial ahli-ahlinya. Ciricirinya termasuklah keakraban, empati berkesan, keterikatan nilai moral, dan kesepaduan sosial yang dapat memenuhi keperluan ahli-ahlinya secara kolektif (Scott, 2014). Jika berdasarkan kepada Teori Hierarki Keperluan oleh Maslow (1958), keperluan-keperluan yang dimaksudkan termasuklah aspek keperluan fisiologi, keselamatan dan sosial yang menyumbang kepada rasa selesa, selamat, dan kekitaan. Semua ini seterusnya menyumbang ke arah pembentukan masyarakat yang lebih bersatu-padu (Forrest \& Kearns, 2001; Norwahidah \& Novel, 2016).

Hubungan antara konsep kejiranan dan kesannya ke atas kesejahteraan sosial dalam masyarakat telah banyak dikaji oleh para penyelidik tempatan dan luar negara. Mcmillan dan Chavis (1986) dan Hyyppä (2010) mendapati individu yang menetap di kawasan yang mempunyai 
hubungan kejiranan yang rapat, cenderung untuk mempunyai kesihatan yang lebih baik daripada segi fizikal, psikologi dan kelakuan yang positif. Penemuan ini disokong oleh Prezza dan Costantini (1998) yang mendapati bahawa orang yang mempunyai ikatan kejiranan yang baik dengan komuniti mereka lebih cenderung untuk mempunyai keyakinan diri yang tinggi dan kemahiran penyelesaian masalah yang baik. Kajian Salmi (2006) pula mendapati hubungan kejiranan yang baik mampu meningkatkan kestabilan dalam politik, mengurangkan kadar jenayah, menjana pembangunan ekonomi dan menjaga kebajikan sosial masyarakat. Penemuan ini menyokong hujah Forrest dan Kearns (2001) bahawa hubungan kejiranan yang baik boleh menyumbang kepada kesepaduan sosial dan modal sosial ahli-ahlinya. Justeru itu, dapat disimpulkan bahawa terdapat banyak kelebihan yang diperolehi daripada hubungan kejiranan yang positif. Malah, kontak sosial dalam organisasi tidak rasmi seperti dalam konteks kejiranan dapat menyumbang kepada kepercayaan sosial (social trust) yang lebih tebal berbanding dalam organisasi rasmi seperti di tempat kerja (Airaksinen, 2008). Keadaan sebegini seterusnya memberi kesan yang positif pada skala yang lebih luas (Granovetter, 1973); lapisan akar-umbi masyarakat yang maju dalam semua aspek seperti rohani, intelektual dan adab, seterusnya akan dapat menyumbang kepada negara yang lebih maju, harmoni, sihat dan bersatu-padu (Hyyppä, 2010; Putnam, 2000).

Signifikasi konsep kejiranan dalam masyarakat tradisional dicontohi dan diaplikasikan dalam pembentukan Skim Rukun Tetangga pada tahun 1969. Pelaksanaannya yang bergerak sebagai sebuah pertubuhan sukarela adalah mirip kepada pertubuhan-pertubuhan yang wujud di negara maju seperti Tonarigumi di Jepun dan Neighbourhood Watch di United Kingdom (Mohd Syariefudin et al., 2013). Pada awalnya, Skim Rukun Tetangga diletakkan di bawah Peraturanperaturan Perlu (Rukun Tetangga) yang digubal di bawah Ordinan Darurat (Kuasa-kuasa Perlu) 1969 (Rashid, 2004). Serentak dengan itu, ia telah dikuatkuasakan di Semenanjung Malaysia bermula dari Kampung Kasipillay di Wilayah Persekutuan Kuala Lumpur sebelum diperluaskan ke Sabah pada 31 Ogos 1985, dan ke Sarawak pada 1 Februari 1988 (Kementerian Perpaduan Negara, 2021). Daripada segi seliaan pula, sejak daripada penubuhannya pada tahun 1969, RT diletakkan di bawah Jabatan Perpaduan Negara yang seterusnya dikenali sebagai Jabatan Perpaduan dan Integrasi Nasional (JPNIN). Namun sejak dari itu, JPNIN sendiri telah bertukar tangan kepada beberapa portfolio dan kini di bawah Kementerian Perpaduan Negara mulai 10 Mac 2020.

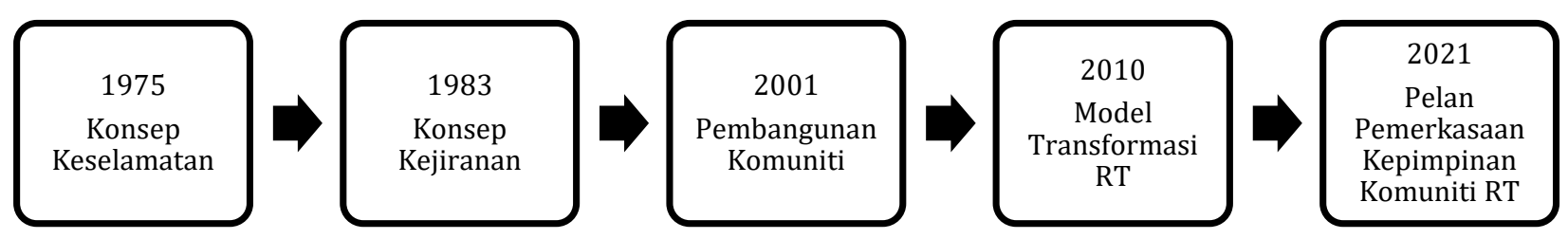

Rajah 1. Fasa perubahan konsep Rukun Tetangga

Rajah 1 menunjukkan evolusi pembentukan dan perkembangan konsep Rukun Tetangga dari awal penubuhannya hingga kini yang diselaraskan dengan perubahan dan keperluan sosioekonomi semasa. Pada awalnya, RT bukan sekadar membantu kerajaan menyemai dan meningkatkan semangat perpaduan, tetapi juga menjaga keselamatan kawasan setempat daripada ancaman komunis. Apabila keadaan menjadi semakin selamat dan stabil, fokus RT dialihkan kepada konsep kejiranan mulai tahun 1983 untuk meningkatkan semangat kejiranan dan perpaduan dalam masyarakat setempat melalui pelbagai aktiviti kejiranan. Faktor modenisasi dan urbanisasi yang pesat menyebabkan fokus RT dipinda sekali lagi pada tahun 2001 kepada aspek 
pembangunan dan pemerkasaan komuniti ke arah meningkatkan keupayaan masyarakat terhadap perubahan sosial dan gaya hidup (Kementerian Perpaduan Negara, 2021). Pada tahun 2010, peranan KRT diselaras dengan Program Transformasi Kerajaan melalui Model Transformasi Rukun Tetangga, namun ianya tidak bertahan lama. Setahun kemudian, Ordinan Darurat 1969 dimansuh dan digantikan dengan Akta Rukun Tetangga 2012 (Akta 751). Akta ini mengangkat fungsi dan peranan RT sebagai "peneraju keharmonian, keselamatan dan perkhidmatan kepada komuniti" (Kementerian Perpaduan Negara, 2021) menerusi pelaksanaan Pelan Pemerkasaan Kepimpinan Komuniti Rukun Tetangga 2021-2030 mulai Februari 2021. Seperti Model Transformasi Rukun Tetangga sebelumnya, Akta 751 memberi keutamaan kepada aspek perpaduan negara berbanding keselamatan (Abd Hadi \& Norwahidah, 2013). Bersandarkan kepada Dasar Perpaduan Negara 2021 dan Rangka Tindakan Perpaduan Negara 2021-2030, pelaksanaan Pelan Pemerkasaan ini dilakukan menerusi aktiviti-aktiviti komuniti yang terangkum dalam empat 'Gerak Kerja KRT' yang bertemakan kesejahteraan, keselamatan, kebersihan dan keindahan, dan kesihatan komuniti (JPNIN, 2021). Sepanjang perkembangannya, matlamat penubuhan RT yang mengutamakan perpaduan dan semangat kejiranan didapati kekal menjadi keutamaan dalam pelaksanaan aktiviti-aktivitinya (Mahani, 2008; JPNIN, 2021).

\section{Metod kajian}

Kajian ini menggunakan pendekatan kuantitatif melalui teknik pengumpulan data dengan menggunakan borang soal selidik. Kaedah ini mampu memberikan gambaran makro yang jelas (Babbie, 2010), justeru sesuai untuk memahami dan mengenal pasti maklumbalas responden terhadap kesepaduan sosial. Konstruk-konstruk digunakan dalam kajian ini disesuaikan daripada konstruk-konstruk yang telah digunakan dalam kajian Indeks Perpaduan Nasional (IPNas) 2018 iaitu hubungan sosial rentas etnik, tingkah laku kemanusiaan, tadbir urus kerajaan dan pembangunan, kesepaduan sosial, etos bangsa, naratif negara bangsa, literasi politik dan media sosial (JPNIN \& KITA, 2019).

Responden kajian terdiri daripada penduduk yang menetap di 60 daripada 8,130 buah kejiranan KRT di seluruh negara. Pemilihan KRT dan responden dilakukan menggunakan pendekatan purposive sampling untuk memastikan komposisi etnik responden kajian adalah selaras dengan komposisi etnik dalam populasi Malaysia iaitu 69.3\% etnik Melayu, 22.8\% etnik Cina, 6.9\% etnik India dan 1.0\% Lain-lain (Jabatan Perangkaan Malaysia, 2019). Sebanyak 600 set borang soal selidik diedarkan melalui pos atau serahan tangan kepada Pegawai Perpaduan Daerah yang berkaitan dari awal bulan Disember 2019 hingga Januari 2020. Mereka seterusnya mengedarkan borang soal selidik tersebut kepada responden dari KRT yang dipilih secara rawak di setiap negeri berdasarkan kriteria yang ditetapkan oleh pengkaji seperti latar belakang etnik dan kawasan tempat tinggal (Jadual 1). Pada bulan Mac 2020, sebanyak 585 set lengkap telah berjaya dikumpulkan.

Langkah seterusnya, data dianalisis melalui dua kaedah. Analisis deskriptif dilakukan berdasarkan peratus dan statistik Pearson Chi-Square menggunakan Statistical Package for the Social Sciences (SPSS) versi 25 untuk melihat perkaitan antara item sama ada ianya mempunyai signifikan atau tidak, dan aras perkaitan yang diambil kira ialah pada tahap $<0.05$. Manakala untuk menghubungkait faktor-faktor dalam mempengaruhi kesepaduan sosial di kalangan masyarakat Malaysia, data dianalisis menggunakan kaedah statistik inferensi bagi menjelaskan peramalan sebab-akibat antara konstruk-konstruk yang dikaji dengan menggunakan Partial Least Square Structural Equation Modelling (PLS-SEM) (JPNIN \& KITA, 2019). 
Jadual 1. Bilangan set soal-selidik yang diedarkan mengikut negeri

\begin{tabular}{cc}
\hline Negeri & Bilangan set \\
\hline Wilayah Persekutuan Kuala Lumpur & 75 \\
Sarawak & 65 \\
Sabah & 60 \\
Pulau Pinang & 55 \\
Negeri Sembilan & 45 \\
Selangor & 40 \\
Perak & 35 \\
Melaka & 35 \\
Kelantan & 35 \\
Pahang & 35 \\
Johor & 30 \\
Perlis & 25 \\
Kedah & 25 \\
Terengganu & 20 \\
Wilayah Persekutuan Labuan & 10 \\
Wilayah Persekutuan Putrajaya & 10 \\
\hline Jumlah & 600 \\
\hline
\end{tabular}

\section{Dapatan dan perbincangan}

Secara keseluruhannya, dapatan kajian menggambarkan majoriti responden bersetuju bahawa Malaysia telah mempunyai kesepaduan sosial yang tinggi yang terserlah melalui perkongsian nilai hidup bersama, mempunyai pandangan hidup persamaan dan bentuk perhubungan yang merentas dan melangkau batas etnik dan agama.

Kesepaduan sosial diukur berdasarkan enam dimensi iaitu kekitaan, keterangkuman, penyertaan, pengiktirafan, legitimasi dan kesamarataan. Jadual 2 menunjukkan majoriti responden tanpa mengira etnik menilai kesepaduan sosial dalam aspek sosio-budaya sebagai positif. Umumnya, majoriti etnik Melayu dan Cina menilai kesepaduan sosial lebih tinggi berbanding dengan responden etnik lain. Majoriti etnik India berpendapat pengagihan kekayaan antara etnik masih kurang seimbang terutamanya dari segi peluang pekerjaan di jabatan kerajaan masih tidak dibuka luas kepada semua kaum. Manakala majoriti etnik bumiputera Sabah dan Sarawak berpendapat bahawa Badan Bukan Kerajaan (NGO) telah diberi layanan yang sama oleh kerajaan.

Bagi dimensi kekitaan, dua item iaitu item 5.7 dan 5.13 didapati menunjukkan perbezaan signifikan (0.041 dan 0.001) antara etnik. Majoriti responden etnik Melayu dan bumiputera Sabah dan Sarawak berpendapat rasa kekitaan dalam kalangan mereka berada pada tahap lebih tinggi berbanding dengan etnik lain walaupun jurang perbezaan peratusan jawapan antara reponden wujud tetapi secara relatifnya adalah kecil. Manakala dua item lagi iaitu item 5.1 dan item 5.18 menunjukkan tidak ada perbezaan signifikan (0.063 dan 0.573) antara etnik. Ini bermaksud majoriti responden tanpa mengira etnik lebih bersetuju kepelbagaian asal usul rakyat Malaysia merupakan aset negara dan pihak berkuasa tempatan menggalakkan pemaju perumahan membina taman perumahan percampuran pelbagai kaum. 
Jadual 2. Kesepaduan sosial mengikut etnik $(\mathrm{n}=585)$

\begin{tabular}{|c|c|c|c|c|c|}
\hline $\begin{array}{l}\text { Dimensi / Item } \\
\text { Jawapan Setuju sahaja }\end{array}$ & $\begin{array}{l}\text { Melayu } \\
(\%)\end{array}$ & $\begin{array}{c}\text { Cina } \\
(\%)\end{array}$ & $\begin{array}{c}\text { India } \\
(\%)\end{array}$ & $\begin{array}{l}\text { Bumiputera } \\
\text { Sabah \& } \\
\text { Sarawak }(\%)\end{array}$ & Pearson Chi-Square \\
\hline $\begin{array}{l}\text { Kekitaan } \\
\text { Kepelbagai asal usul rakyat Malaysia } \\
\text { merupakan aset negara. }(5.1)\end{array}$ & 96.7 & 99.3 & 99.1 & 100.0 & $\begin{array}{l}\text { Nilai: } 20.228^{a} \\
\text { Darjah Kebebasan: } 12 \\
\text { Nilai Signifikan: } .063\end{array}$ \\
\hline $\begin{array}{l}\text { Banyak program sosio-budaya mendapat } \\
\text { sambutan rakyat. (5.7) }\end{array}$ & 92.1 & 96.0 & 92.2 & 96.1 & $\begin{array}{l}\text { Nilai: } 21.703^{\mathrm{a}} \\
\text { Darjah Kebebasan: } 12 \\
\text { Nilai Signifikan: .041 }\end{array}$ \\
\hline $\begin{array}{l}\text { Bersimpati jika kenalan daripada etnik lain } \\
\text { meninggal dunia. (5.13) }\end{array}$ & 98.3 & 97.3 & 96.6 & 100.0 & $\begin{array}{l}\text { Nilai: } 34.778^{\text {a }} \\
\text { Darjah Kebebasan: } 12 \\
\text { Nilai Signifikan: .001 }\end{array}$ \\
\hline $\begin{array}{l}\text { Menggalakkan pemaju perumahan } \\
\text { membina taman perumahan percampuran } \\
\text { pelbagai kaum. }(5.18)\end{array}$ & 94.2 & 95.3 & 93.1 & 96.1 & $\begin{array}{l}\text { Nilai: } 10.487^{\text {a }} \\
\text { Darjah Kebebasan: } 12 \\
\text { Nilai Signifikan: } .573\end{array}$ \\
\hline $\begin{array}{l}\text { Keterangkuman } \\
\text { Peluang pekerjaan di jabatan kerajaan } \\
\text { amat terbuka. }(5.16)\end{array}$ & 90.9 & 82.0 & 68.1 & 96.1 & $\begin{array}{l}\text { Nilai: } 48.981^{\mathrm{a}} \\
\text { Darjah Kebebasan: } 12 \\
\text { Nilai Signifikan: } .000\end{array}$ \\
\hline $\begin{array}{l}\text { Tidak terpinggir dalam mendapat peluang } \\
\text { untuk memiliki rumah. (5.19) }\end{array}$ & 93.0 & 92.7 & 88.8 & 92.2 & $\begin{array}{l}\text { Nilai: } 16.858^{\mathrm{a}} \\
\text { Darjah Kebebasan: } 12 \\
\text { Nilai Signifikan: } .155\end{array}$ \\
\hline $\begin{array}{l}\text { Peluang pendidikan ke IPTA terbuka luas } \\
\text { untuk semua. }(5.20)\end{array}$ & 94.6 & 82.0 & 88.8 & 96.1 & $\begin{array}{l}\text { Nilai: } 49.194^{\mathrm{a}} \\
\text { Darjah Kebebasan: } 12 \\
\text { Nilai Signifikan: } .000\end{array}$ \\
\hline Bantuan kerajaan mudah diperolehi. (5.23) & 80.2 & 84.0 & 83.6 & 77.9 & $\begin{array}{l}\text { Nilai: } 13.466^{\mathrm{a}} \\
\text { Darjah Kebebasan: } 12 \\
\text { Nilai Signifikan: } .336\end{array}$ \\
\hline $\begin{array}{l}\text { Penyertaan } \\
\text { Bebas mengundi calon / parti politik yang } \\
\text { digemari. (5.2) }\end{array}$ & 97.5 & 99.3 & 100.0 & 100.0 & $\begin{array}{l}\text { Nilai: } 12.138^{a} \\
\text { Darjah Kebebasan: } 12 \\
\text { Nilai Signifikan: } .435\end{array}$ \\
\hline $\begin{array}{l}\text { Bebas membincangkan hal-hal politik. } \\
\text { (5.3) }\end{array}$ & 95.5 & 98.0 & 95.7 & 96.1 & $\begin{array}{l}\text { Nilai: } 15.489^{a} \\
\text { Darjah Kebebasan: } 12 \\
\text { Nilai Signifikan: } .216\end{array}$ \\
\hline $\begin{array}{l}\text { Aktiviti persatuan dan badan kebajikan } \\
\text { disertai oleh pelbagai kaum. (5.8) }\end{array}$ & 93.8 & 98.0 & 97.4 & 100.0 & $\begin{array}{l}\text { Nilai: } 38.345^{\mathrm{a}} \\
\text { Darjah Kebebasan: } 12 \\
\text { Nilai Signifikan: } .000\end{array}$ \\
\hline $\begin{array}{l}\text { Penglibatan dalam NGO sangat terbuka. } \\
(5.15)\end{array}$ & 95.0 & 96.7 & 88.8 & 100.0 & $\begin{array}{l}\text { Nilai: } 37.292^{\mathrm{a}} \\
\text { Darjah Kebebasan: } 12 \\
\text { Nilai Signifikan: } .000\end{array}$ \\
\hline $\begin{array}{l}\text { Pengiktirafan } \\
\text { Memberi pingat penghargaan kepada } \\
\text { rakyat yang berjasa. }(5.4)\end{array}$ & 93.4 & 97.3 & 95.7 & 83.5 & $\begin{array}{l}\text { Nilai: } 15.601^{\mathrm{a}} \\
\text { Darjah Kebebasan: } 12 \\
\text { Nilai Signifikan: } .210\end{array}$ \\
\hline $\begin{array}{l}\text { Berjaya mengukuhkan tadbir urus dan } \\
\text { pembangunan yang baik. }(5.5)\end{array}$ & 81.0 & 90.0 & 87.9 & 64.4 & $\begin{array}{l}\text { Nilai: } 17.467^{\mathrm{a}} \\
\text { Darjah Kebebasan: } 12 \\
\text { Nilai Signifikan: } .133\end{array}$ \\
\hline $\begin{array}{l}\text { Menerima simbol-simbol agama lain. } \\
\text { (5.9) }\end{array}$ & 85.5 & 96.0 & 98.3 & 83.9 & $\begin{array}{l}\text { Nilai: } 50.313^{\mathrm{a}} \\
\text { Darjah Kebebasan: } 12 \\
\text { Nilai Signifikan: } .000\end{array}$ \\
\hline $\begin{array}{l}\text { Perbezaan pandangan pelbagai etnik } \\
\text { merupakan amalan sihat. }(5.12)\end{array}$ & 90.5 & 91.3 & 87.9 & 90.4 & $\begin{array}{l}\text { Nilai: } 37.249^{a} \\
\text { Darjah Kebebasan: } 12 \\
\text { Nilai Signifikan: } .000\end{array}$ \\
\hline $\begin{array}{l}\text { Legitimasi } \\
\text { Janji dan manifesto ahli-ahli pemimpin } \\
\text { tidak boleh dipercayai. (5.6) }\end{array}$ & 89.3 & 87.3 & 83.6 & 92.2 & $\begin{array}{l}\text { Nilai: } 8.358^{\mathrm{a}} \\
\text { Darjah Kebebasan: } 12\end{array}$ \\
\hline
\end{tabular}




\begin{tabular}{|c|c|c|c|c|c|}
\hline $\begin{array}{l}\text { Wujudnya undang-undang berkaitan } \\
\text { agama yang berbeza. }(5.10)\end{array}$ & 91.7 & 96.0 & 94.8 & 98.7 & $\begin{array}{l}\text { Nilai Signifikan: .757 } \\
\text { Nilai: } 13.800^{\mathrm{a}} \\
\text { Darjah Kebebasan: } 12 \\
\text { Nilai Signifikan: } .314\end{array}$ \\
\hline $\begin{array}{l}\text { Berwaspada apabila menerima berita- } \\
\text { berita kepincangan tadbir urus kerajaan } \\
\text { daripada media sosial. (5.11) }\end{array}$ & 96.3 & 95.3 & 92.2 & 100.0 & $\begin{array}{l}\text { Nilai: } 29.707^{\mathrm{a}} \\
\text { Darjah Kebebasan: } 12 \\
\text { Nilai Signifikan: .003 }\end{array}$ \\
\hline $\begin{array}{l}\text { Badan Bukan Kerajaan (NGO) tidak diberi } \\
\text { layanan yang sama. (5.14) }\end{array}$ & 79.8 & 80.0 & 79.3 & 63.6 & $\begin{array}{l}\text { Nilai: } 24.964^{\mathrm{a}} \\
\text { Darjah Kebebasan: } 12 \\
\text { Nilai Signifikan: .015 }\end{array}$ \\
\hline $\begin{array}{l}\text { Kesamarataan } \\
\text { Pekerja asing telah merampas peluang } \\
\text { pekerjaan rakyat tempatan. (5.17) }\end{array}$ & 87.6 & 86.7 & 90.5 & 80.5 & $\begin{array}{l}\text { Nilai: } 20.979^{a} \\
\text { Darjah Kebebasan: } 12 \\
\text { Nilai Signifikan: .051 }\end{array}$ \\
\hline $\begin{array}{l}\text { Pelajar yang mendapat 9A diberi biasiswa } \\
\text { ke IPT. (5.21) }\end{array}$ & 92.1 & 86.0 & 87.9 & 96.1 & $\begin{array}{l}\text { Nilai: } 46.260^{\mathrm{a}} \\
\text { Darjah Kebebasan: } 12 \\
\text { Nilai Signifikan: } .000\end{array}$ \\
\hline Mudah memperolehi bantuan Polis. (5.22) & 95.5 & 96.7 & 99.1 & 94.8 & $\begin{array}{l}\text { Nilai: } 35.858^{\text {a }} \\
\text { Darjah Kebebasan: } 12 \\
\text { Nilai Signifikan: } .000\end{array}$ \\
\hline $\begin{array}{l}\text { Jurang kemiskinan antara kaum masih } \\
\text { ketara. (5.24) }\end{array}$ & 94.6 & 90.7 & 87.9 & 93.5 & $\begin{array}{l}\text { Nilai: } 24.489^{\text {a }} \\
\text { Darjah Kebebasan: } 12 \\
\text { Nilai Signifikan: .017 }\end{array}$ \\
\hline
\end{tabular}

Untuk dimensi keterangkuman, dua item iaitu item 5.16 dan item 5.20 menunjukkan terdapat perbezaan signifikan (0.000 dan 0.000) antara etnik. Ini menggambarkan secara relatifnya, majoriti responden etnik India berpendapat peluang pekerjaan di jabatan kerajaan masih tidak dibuka luas kepada semua kaum berbanding dengan responden etnik lain. Majoriti responden etnik Melayu, Cina dan bumiputera Sabah dan Sarawak pula lebih bersetuju bahawa mereka telah diberi peluang yang sama dan adil dalam pendidikan ke IPTA. Manakala dua item lagi iaitu item 5.19 dan item 5.23 menunjukkan tiada perbezaan signifikan (0.155 dan 0.336) antara etnik. Ini bermaksud majoriti responden tanpa mengira etnik lebih bersetuju bahawa mereka telah diberi peluang yang sama dalam pemilikan rumah dan bantuan kerajaan mudah diperolehi oleh mereka.

Bagi dimensi penyertaan pula, dua item iaitu item 5.8 dan item 5.15 menunjukkan terdapat perbezaan signifikan (0.000 dan 0.000) antara etnik. Ini menunjukkan bahawa secara relatifnya $100 \%$ responden etnik bumiputera Sabah dan Sarawak berpendapat aktiviti persatuan dan badan kebajikan disertai oleh pelbagai kaum dan penglibatan dalam NGO di negara ini adalah sangat terbuka berbanding dengan responden etnik lain. Manakala dua item lagi iaitu item 5.2 dan item 5.3 menunjukkan tidak ada perbezaan signifikan ( 0.435 dan 0.216 ) antara etnik. Ini bererti majoriti responden tanpa mengira etnik lebih bersetuju rakyat diberi kebebasan mengundi calon atau parti politik dan bebas membincangkan hal-hal politik.

Bagi dimensi pengiktirafan, dua item iaitu item 5.9 dan item 5.12 menunjukkan terdapat perbezaan signifikan (0.000 dan 0.000) antara etnik. Secara relatifnya, majoriti responden etnik Cina dan India lebih bersetuju dan boleh menerima simbol-simbol agama lain. Majoriti responden etnik Melayu dan bumiputera Sabah dan Sarawak lebih bersetuju bahawa perbezaan pandangan pelbagai etnik merupakan amalan sihat di Malaysia. Manakala dua item lagi iaitu 5.4 dan item 5.5 menunjukkan tidak ada perbezaan signifikan (0.210 dan 0.133) antara etnik. Ini bermaksud majoriti responden tanpa mengira etnik lebih bersetuju pihak pemerintah sentiasa memberi pingat penghargaan kepada rakyat yang berjasa kepada negara dan pemerintah negara ini telah berjaya mengukur tadbir urus dan pembangunan negara. 
Untuk dimensi legitimasi, item 5.11 dan item 5.14 menunjukkan terdapat perbezaan signifikan (0.003 dan 0.015) antara etnik. Ini menggambarkan majoriti responden etnik Melayu, Cina dan India secara relatifnya lebih bersetuju Badan Bukan Kerajaan (NGO) tidak diberi layanan yang sama di negara ini. 100\% responden etnik bumiputera Sabah dan Sarawak pula bersetuju mereka akan berwaspada apabila menerima berita-berita kepincangan tadbir urus kerajaan daripada media sosial. Manakala dua item lagi iaitu item 5.6 dan item 5.10 menunjukkan tidak ada perbezaan signifikan (0.757 dan 0.314) antara etnik. Ini bermaksud majoriti responden tanpa mengira etnik lebih bersetuju bahawa janji dan manifesto ahli-ahli pemimpin tidak boleh dipercayai dan mereka juga mengakui masih wujudnya undang-undang berkaitan agama yang berbeza.

Bagi dimensi kesamarataan, hanya item 5.17 didapati menunjukkan tiadanya perbezaan signifikan (0.051) antara etnik. Ini menggambarkan majoriti responden tanpa mengira etnik lebih bersetuju bahawa pekerja asing telah merampas peluang pekerjaan rakyat tempatan. Tiga item lain iaitu item 5.21, item 5.22 dan item 5.24 menunjukkan terdapat perbezaan signifikan $(0.000,0.000$ dan 0.017) antara etnik. Ini bererti majoriti responden etnik Melayu dan bumiputera Sabah dan Sarawak secara relatifnya lebih bersetuju bahawa pelajar yang cemerlang telah diberi biasiswa ke IPT dan jurang kemiskinan antara kaum masih ketara. Majoriti responden etnik Cina dan India lebih bersetuju bahawa mereka lebih mudah mendapat bantuan jika berada dalam kesusahan.

Hasil analisis juga mendapati faktor-faktor yang mempengaruhi secara langsung dan signifikan terhadap kesepaduan sosial adalah faktor hubungan sosial rentas etnik $(\beta=0.124$, $\mathrm{t}=2.847, \mathrm{p}=0.004, \mathrm{CI}[0.038,0.210]$, tadbir urus kerajaan dan pembangunan $(\beta=0.541, \mathrm{t}=16.644$, $\mathrm{p}=0.000, \mathrm{CI}[0.477,0.605])$, naratif negara bangsa $(\beta=0.147, \mathrm{t}=3.366, \mathrm{p}<0.001, \mathrm{CI}[0.061,0.233])$, literasi politik $(\beta=-0.081, \mathrm{t}=2.760, \mathrm{p}=0.006, \mathrm{CI}[-0.140,-0.022])$ dan media sosial $(\beta=-0.072$, $\mathrm{t}=2.068, \mathrm{p}=0.039, \mathrm{CI}[0.001,0.139])$ seperti di Jadual 3.

Jadual 3. Penilaian kesignifikan dan kerelevanan konstruk

\begin{tabular}{lcccc}
\hline \multicolumn{1}{c}{ Hubungan } & $\begin{array}{c}\text { Pekali Koefisien } \\
(\text { Nilai } \beta)\end{array}$ & Nilai t & Nilai p & 95\% CI \\
\hline HSRE -> KS & 0.124 & 2.847 & $0.004^{*}$ & {$[0.038,0.210]$} \\
TU\&P -> KS & 0.541 & 16.644 & $0.000^{*}$ & {$[0.477,0.605]$} \\
NNB -> KS & 0.147 & 3.366 & $0.001^{*}$ & {$[0.061,0.233]$} \\
LP -> KS & -0.081 & 2.760 & $0.006^{*}$ & {$[-0.140,-0.022]$} \\
MS -> KS & 0.072 & 2.068 & $0.039^{*}$ & {$[0.001,0.139]$} \\
TLK -> KS & 0.048 & 1.116 & 0.264 & {$[-0.038,0.128]$} \\
EB -> KS & 0.069 & 1.491 & 0.136 & {$[-0.022,0.159]$} \\
\hline
\end{tabular}

Nota: *signifikan pada tahap nilai $\mathrm{p}<0.05, \mathrm{~EB}=$ Etos Bangsa, HSRE=Hubungan Sosial Rentas Etnik, KS=Kesepaduan Sosial, LP=Literasi Politik, MS=Media Sosial, NNB=Naratif Negara Bangsa, TU\&P=Tadbir Urus Kerajaan \& Pembangunan, TLK=Tingkah Laku Kemanusiaan

Manakala konstruk hubungan sosial rentas etnik (HSRE), tadbir urus kerajaan dan pembangunan (TU\&P), tingkah laku kemanusiaan (TLK), naratif negara bangsa (NNB), literasi politik (LP), media sosial (MS) dan etos bangsa (EB) secara bersama telah menyumbang nilai varian $\mathrm{R}^{2}$ sebanyak $54.6 \%\left(\mathrm{R}^{2}=0.546\right)$ kepada kesepaduan sosial $(\mathrm{KS})$. 


\section{Kesimpulan}

Secara kesimpulannya, hasil kajian ini menunjukkan bahawa kesepaduan sosial dalam kalangan penduduk KRT di seluruh negara telah terbina. Ini berdasarkan nilai varian keseluruhan yang terkumpul dalam konstruk kesepaduan sosial iaitu $\mathrm{R}^{2}=0.546$. Nilai indeks ini adalah tinggi berdasarkan skala antara 0 hingga 1 yang dinyatakan oleh Cohen (1988) sebagai petunjuk yang sesuai bagi kajian sains tingkah laku manusia. Nilai yang tinggi ini menggambarkan bahawa pada peringkat akar umbi masyarakat yang dilihat melalui perspektif tafsiran harian (Shamsul, 2012), penduduk Malaysia daripada pelbagai latar belakang etnik mampu berkongsi nilai hidup dan pandangan hidup yang sama. Dalam konteks KRT, proses penyatupaduan masyarakat berlaku dengan lebih berkesan hasil pelaksanaannya melalui RT yang merupakan sebuah organisasi bukan formal yang tersusun, inklusif, dan berwawasan yakni ke arah pembentukan Bangsa Malaysia yang berlandaskan Rukun Negara melalui konsep pembangunan komuniti (JPNIN, 2021). Pengukuran kesepaduan sosial dalam kajian ini turut menunjukkan bahawa walaupun penduduk KRT mempunyai bentuk perhubungan yang merentasi batas etnik, signifikasi faktor etnik belum terhapus sepenuhnya dalam masyarakat Malaysia. Penemuan kajian ini penting, lebih-lebih lagi dalam masyarakat semasa berhadapan dengan keadaan politik yang tidak stabil akibat daripada pergolakan dalaman parti politik dan tadbir urus negara, selain daripada kegawatan sosioekonomi yang tercetus daripada pandemik Covid-19 yang sedang melanda dunia kini. Justeru itu, semua pihak khasnya di peringkat berautoriti adalah disarankan supaya mengambil iktibar daripada keadaan ini dan berusaha bersama-sama dengan RT dan JPNIN untuk meningkatkan perpaduan dalam masyarakat ke tahap yang lebih kukuh.

\section{Penghargaan}

Artikel ini merupakan sebahagian daripada tesis kedoktoran Pengarang Utama di bawah program Hadiah Latihan Persekutuan (HLP), Jabatan Pengajian Awam.

\section{Rujukan}

Abd Aziz, A., Farrah, W.M., Aimi, K.A.K., \& Nurliana, S. (2017). Realiti kepelbagaian kaum ke arah perpaduan nasional pasca merdeka. Jurnal Sains Sosial Malaysian, 2, 1-24.

Abd Hadi, M.S., \& Norwahidah, Z. (2013). Panduan pengurusan Rukun Tetangga. Kuala Lumpur: JPNIN.

Ahmad, Z.S.A.S., \& Nur Syafiqah, H.M.R. (2014). Penerimaan masyarakat terhadap aktiviti Rukun Tetangga mengikut jantina. Al-Hikmah, 6(2), 110-127.

Airaksinen, T. (2008). Trust, Responsibility, Power, and Social Capital. In Braham, M., \& Steffen, F. (Eds.). Power, freedom, and voting: Essays in honour of Manfred J. Holler, (pp. 405420). Berlin: Springer-Verlag.

Anis, S.A., Zuriadah, I., Anuar, S., \& Nurhanie, M. (2018). Governing by Bumiputera hegemony and predatory state power: challenges in regulatory reforms in Malaysia. Journal of Legal, Ethical and Regulatory Issues, 21(4), 1-9.

Babbie, E. (2010). The practice of social research. (12 ${ }^{\text {th }}$ Ed.). Belmont: Wadsworth Cengage Learning. 
Barth, F. (Ed.). (1969). Ethnic groups and boundaries: The social organization of culture difference. Boston: Little, Brown and Company.

Budi, A.M.T., Mohd Sohaimi, E., \& Mohd Azri, I. (2020). Hubungan kaum dalam kawasan Rukun Tetangga (KRT) di Pantai Barat Sabah. Malaysian Journal of Social Sciences and Humanities, 5(11), 147-158.

Cheah, B.K. (1983). Red star over Malaya: Resistance and social conflict during and after the Japanese Occupation 1941-46. Singapore: Singapore University Press.

Chia, J. (2013). Kampong spirit gotong royong: Life in Potong Pasir, 1955 to 1965. Singapore: Marshall Cavendish.

Chin, Y.M, Lee, Y.F., Jayum, J., \& Darshan, S.S. (2015). From individual choice to collective actions: ethnic consciousness in Malaysia reconsidered. Ethnic and Racial Studies, 38(2), 259-294.

Cohen, J. (1988). Statistical power analysis for the behavioral sciences. ( $2^{\text {nd }}$ Ed.). Hillsdale: Laurence Erlbaum Associates.

Del Tufo, M.V. (1949). A report on the 1947 census of population. Singapore: The Government Publications Bureau Singapore.

Faris, I.M.A.R., Muhamad Sayuti, H.Y., \& Nizamuddin, A. (2017). The role of Neighbourhood Watch in reducing crimes in the community. The European Proceedings of Social \& Behavioural Sciences, 52, 808-814.

Forrest, R., \& Kearns, A. (2001). Social cohesion, social capital and the neighbourhood. Urban Studies, 38(12), 2125-2143.

Granovetter, M.S. (1973). The strength of weak ties. American Journal of Sociology, 78(6), 13601380.

Hamidah, A.B. (2014). Kepimpinan Rukun Tetangga: Satu kajian kes di kawasan Rukun Tetangga Kampung Malaysia Raya, Cheras, Kuala Lumpur (Masters thesis). Universiti Sains Malaysia.

Ho, H.L. (2005). Darurat 1948-1960: Keadaan sosial di Tanah Melayu. Kuala Lumpur: Penerbit Universiti Malaya.

Hyyppä, M.T. (2010). Healthy ties: Social capital, population health and survival. London: Springer.

Jabatan Perangkaan Malaysia. (2019). Siaran akhbar anggaran penduduk semasa Malaysia, 20182019, 15 Julai. https://www.dosm.gov.my.

Jabatan Perpaduan Negara dan Integrasi Nasional (JPNIN) \& Institut Kajian Etnik (KITA). (2019). Laporan akhir Indeks Perpaduan Nasional, 2018. Putrajaya: JPNIN.

Jabatan Perpaduan Negara dan Integrasi Nasional (JPNIN). (2021). Panduan pengurusan dan pentadbiran Rukun Tetangga. Putrajaya: Kementerian Perpaduan Negara.

Joseph, C. (2018). Malaysian geopolitics, ethnoscapes and education policy. In Joseph, C. (Ed.), Policies and politics in Malaysian education: Education reforms, nationalism and neoliberalism (pp. 1-16). Oxon: Routledge.

Kementerian Perpaduan Negara. (2021). Pelan pemerkasaan kepimpinan komuniti Rukun Tetangga 2021-2030. Putrajaya: Kementerian Perpaduan Negara.

Khairul, S.A.A., \& Rozaimah, Z. (2020). Money in politics: a recipe for corruption in Malaysia. Journal of Financial Crime, online first, https://doi.org/https://doi.org/10.1108/JFC-072020-0147. 
Khoo, S.L., Mohamad Shaharudin, S., Gopal, P.S., Nor Malina, M., \& Zahri, H. (2018). Urban poverty alleviation strategies from multi-dimensional and multi-ethnic perspectives: evidences from Malaysia. Kajian Malaysia, 36(2), 43-68.

Lau, A.W.W. (2014). A primordial anxiety: ontological trauma and ethnic solidarity in Malaysia. Asian Journal of Social Science, 42, 291-320.

Lee, H.A., \& Muhammad, A.K. (2013). Degrees of discrimination: race and graduate hiring in Malaysia. Paper presented at the Siri Seminar IKMAS, Institut Kajian Malaysia dan Antarabangsa (IKMAS).

Lino, M., Hashim, I.H.M., \& Ricardo, R. (2017). The lurking racism: exploring racial microaggression in the Malaysian university setting. Pertanika Journal of Social Science and Humanities, 25(1), 473-484.

Mahani, A.B. (2008). Semangat kejiranan. Kuala Lumpur: Pustaka Buana.

Majlis Gerakan Negara. (1969). The May 13 tragedy: A report. Kuala Lumpur: Majlis Gerakan Negara.

Mansor, M.N. (2012). Kerencaman sosial dan penipisan batas etnik: Kepelbagaian etnik dan perkongsian hidup bersama di Malaysia. Bangi: Penerbit UKM.

Mansor, M.N. (2015). Gelombang baru hubungan etnik di Malaysia: Kerencaman sosial, perkongsian norma hidup dan hubungan rentas etnik di Malaysia. Bangi: Universiti Kebangsaan Malaysia.

Maslow, A.H. (1958). A dynamic theory of human motivation. In Stacey, C.L., \& DeMartino, M. (Eds.), Understanding human motivation (pp. 26-47). Cleveland: Howard Allen.

Mcmillan, D.W., \& Chavis, D.M. (1986). Sense of community: a definition and theory. Journal of Community Psychology, 14(1), 6-13.

Mohamed, A.H., \& Ayu, N.A.M. (2017). Impak penjajahan British dan Jepun terhadap hubungan Melayu-Cina di Tanah Melayu. Jurnal Sultan Alauddin Sulaiman Shah, 4(2), 94-106.

Mohd Razali, A. (1992). Pembangunan perumahan: Isu dan prospek. Kuala Lumpur: Dewan Bahasa dan Pustaka.

Mohd Rizal, Y., \& Shamrahayu, A.A. (2014). Kontrak sosial: Perlembagaan Persekutuan 1957 pengikat jati diri bangsa Malaysia merdeka. Kuala Lumpur: Institut Terjemahan \& Buku Malaysia.

Mohd Syariefudin, A., Mansor, M.N., Ahmad Rizal, M.Y., \& Faridah, C.H. (2017). Social cohesion in Rukun Tetangga (Neighbourhood Watch) in Hulu Langat, Selangor, Malaysia. E-Bangi, 2, 57-72.

Mohd Syariefudin, A., Mohd Mahadee, I., \& Mansor, M.N. (2013). Kesepaduan sosial dan kejiranan di kawasan Rukun Tetangga. Jurnal Kinabalu, 19, 53-75.

Mohd Taib, D., Izaidin, A.M., Raja Roslan, R.A.R., Norliah, K., Zawiah, H.M., \& Noor Maslian, O. (2008). City as an urban social diversity: a case study of Rukun Tetangga in Kuala Lumpur and Selangor. Journal of Human Capital Development, 1(1), 75-83.

Muhammad Arif, I., Muhammad Nurul, H., Bui, B., \& van Zijl, T. (2017). Punishment of bribery and corruption: evidence from the Malaysian judicial system. Wellington: Victoria University of Wellington.

Muhammad Najit, S., Berma, M., Shamsul, A.B., \& Faridah, S. (2018). Pengaruh tindakan afirmatif kepada agihan kekayaan antara etnik di Malaysia. Jurnal Ekonomi Malaysia, 52(1), 269-281.

Nazri, M. (2020). The transformation of ethnic relations in Malaysia. Humanities and Social Sciences Letters, 8(3), 252-263. 
Norwahidah, Z., \& Novel, L. (2016). Makna rasa selamat komuniti Malaysia dalam Program Skim Rondaan Sukarela: Kajian kes KRT Taman Putera Jaya, Kota Kinabalu, Sabah. GeografiaMalaysian Journal of Society and Space, 12(5), 22-32.

Prezza, M., \& Costantini, S. (1998). Sense of community and life satisfaction: Investigation in three different territorial contexts. Journal of Community \& Applied Social Psychology, 8(3), 181-194.

Pue, G.H., \& Kaur, C. (2014). Identiti etnik minoriti di Malaysia: antara realiti sosial tafsiran autoriti dan tafsiran harian. Akademika, 84(1 \& 2), 57-70.

Putnam, R.D. (2000). Bowling alone: The collapse and revival of American community. New York: Simon \& Schuster.

Rashid, S. (2004). Sumbangan Rukun Tetangga 21 dalam perpaduan negara dan pembangunan komuniti. In Dani Salleh (Ed.), Pembangunan komuniti: Dasar, konsep, strategi dan isu di Malaysia (pp. 1-3). Sintok: Penerbit Universiti Utara Malaysia.

Ratnam, K.J. (1965). Communalism and the political process in Malaysia. Kuala Lumpur: University of Malaya Press.

Ravallion, M. (2019). Ethnic inequality and poverty in Malaysia since 1969. NBER Working Paper Series. https://www.nber.org/papers/w25640.

Raybeck, D. (1980). Ethnicity and accommodation: Malay-Chinese relations in Kelantan, Malaysia. Ethnic Groups, 2(3), 241-268.

Salmi, V. (2006). The association between social capital and juvenile crime: The role of individual and structural factors. European Journal of Criminology, 3(2), 123-148.

Scott, J. (2014). Oxford dictionary of sociology. (4 ${ }^{\text {th }}$ ed.). Oxford: Oxford University Press.

Shamsul, A.B. (2011). Kesepaduan dalam kepelbagaian: Perpaduan di Malaysia sebagai workin-progress. Bangi: Institut Kajian Etnik.

Shamsul, A.B. (2014). Perpaduan, kesepaduan dan penyatupaduan: Satu negara, satu kata akar, tiga konsep keramat. Paper presented at the Persidangan Pemantapan Citra Kenegaraan: Perkongsian Pengalaman, 19-21 Januari, Universiti Kebangsaan Malaysia.

Shamsul, A.B. (Ed). (2012). Modul hubungan etnik. ( $2^{\text {nd }}$ Ed.). Bangi: Institut Kajian Etnik.

Sity, D., \& Norrizan, A.M. (2019). Challenges of nation-building and the formation of Bangsa Malaysia. Southeast Asian Social Science Review, 4(1), 30-47.

Ting, H.M.H., \& Chang, Y.S. (2018). Asal-usul perjuangan masyarakat sivil Cina di Malaya tentang persoalan perlembagaan kemerdekaan terutamanya persoalan Jus Soli. Kajian Malaysia, 36(2), 113-146.

Wan Zumaiza, W.M., Gill, S.S., \& Ismi, A.I. (2016). Penglibatan jiran muda dalam aktiviti Rukun Tetangga di daerah Hulu Langat, Selangor. Malaysian Journal of Youth Studies, 14(6), 261-276.

Yang, L.F., \& Md. Sidin, A.I. (2015). Gatekeeping in the coverage of interethnic conflicts: an analysis of mainstream and alternative newspapers in Malaysia. SEARCH: The Journal of the South East Asia Research Centre for Communications and Humanities, 7(1), 23-51. 